\title{
Clinical, Diagnosticand Remedial circumference Reflecting Dengue Viral Infection
}

\author{
Irfan kalam ${ }^{1}$, Qaisar Ali $^{2}$, Fazal Mabood ${ }^{3}$ \\ ${ }^{1,2,3}$ Imperial college of buiseness studies Lahore, Pakistan
}

\section{Received: 02 April,2019 \\ Accepted:09 June,2019 \\ *Correspondence to: \\ Dr. Irfan Kalam,}

Email: irfankalam63@yahoo.com

Copyright: () the author(s), publisher and licensee Indian Academy of Pharmacists.

This is an open-access article distributed under the terms of the Creative Commons Attribution Non-Commercial License, which permits unrestricted non-commercial use, distribution, and reproduction in any medium, provided the original work is properly cited.

\section{Published by: OZZIE Publishers}

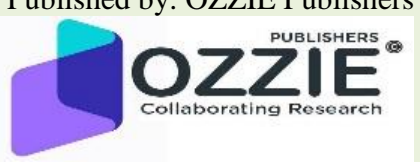

\begin{abstract}
Dengue is one of the burning global health issue for it claims the lives thousands of people due to its fatal nature, it upsurges various phases, namely subclinical infection, undifferentiated febrile fever, Dengue fever (DF) and devastating states which often ends to life, they are Dengue heamorrhagic fever (DHF) and Dengue shock syndrome (DSS). Dengue infection is a mosquito born disease which has engulfed many regions in general and tropical zone in particular, causing many casualties and has posed a threat to humanity, demanding strategies to resolve the global issue. It is reported that 50-200 million people fall prey to it globally by dint of its causative agents and imperative to mention that over proportional are the minor among the victims. Because of awful joint pain dengue fever is also named break bone fever. The common indicator in infected individuals is thrombocytopenia, coagulopathy and vasculopathy. Apart from supportive therapy, no aphoristic therapy has been introduced so far, however care may prove rescuer. Timely prognosis thwarts to enter it in deteriorating phase. In the list of laboratory diagnosis virus serology and detection of Ribonucleic acid are primed. Latest review emphasizes a detail summary on dengue infection, prognosis of numerous clinical manifestations, laboratory Diagnosis and management of different phases of infection.
\end{abstract}

Keywords: Dengue fever, Dengueheamorrhagicfever, Dengueshock syndrome, thrombocytopenia

\section{INTRODUCTION}

Dengue virus infection can lead to spectrum of illness,initially moderate febrile illness to gradually riskier folds like hemorrhagic disorders; Dengue hemorrhagic fever ( DHF ) and Dengue shock syndrome( DSS)(1). Majorly it is self-limiting whereas in minor cases it develops serious complications in the form of DHF; having got its roots from south east, claiming the lives of number of peoples, the aforementioned clinical phase is based on increased vascular permeability and haemoconcentration, leading to DSS; (2-4) most delicate phase of dengue infection posing to hypovolumic shock clinically fluctuation in plasma level and RBCs count, which is alarming. Extensive studies on DHF shows that emergence of two dengue serotypes in an area at the same time can peril DHF. Serologic research reveals that inheritance of secondary antibodies can worsen DHF phase.

Presently no specific antiviral therapy available, however severe complications can be prevented through instant detection and suitable management(5-9). It is broadly reported these days, that dengue complications threatening the whole world community both tropically and subtropically, according to World health organization ( WHO ) dengue virus is awfully turning saddening issues due to fertility, environmental factors, inappropriate prevention of vector, lack of health care facilities and lethargy of concern authorities, so for 30 folds increases has been witnessed from 1960-2010 (10-12). Four genetically distinct serotypes are identified up to date i.e. Den-1, Den-2, Den-3, and Den 4, all of them have the ability to cause severe illness (DHF/DSS), In Asian region Den-2 and Den-3 are more frequently found and these are associated with severe complications $(13,14)$. Infection with one serotype may lead to produce immunity against that particular serotype.infection with another serotype in future may lead to severe complications, i.e. thrombocytopenia and increased vascular permeability, which can result in hemorrhagic and shock complications. The latest review put stress upon clinical, diagnostic and management aspects of Dengue infection transparently.

\section{GLOBAL BURDEN}

Throughout the $19^{\text {th }}$ century, dengue was considered a sporadic disease, causing epidemic at long intervals, but now dramatic changes occur in this hearsay, presently it is considered an important mosquito born disease. In the past 50 years, Dengue virus hit a depicting ratio of the world population and its prevalence is dramatically scaling up with enormous outbreaks (15-17). Recently WHO claim that Approximately 3.6 billion of the world populations are residing in tropical and subtropical region, are at stake. Aedes mosquitoes are scattered in these regions. Presently more than 125 countries are effected by dengue virus, 
including: south East Asia, United States of America, western pacific and in African countries (18). Each year approximately 50-200 million new cases emerge of DF, out of it 500,000 cases turn threatening (DHF/DSS), consequently near to 20,000 people die due to the complication of the virus, amongst the victims $90 \%$ are innocent childrens having age less than 15 years $(19,20)$. DHF was $1^{\text {st }}$ investigated in Manila in 1954, now it is spread approximately all over the world. major epidemics of the dengue virus were happened in 1980s-90s, the predominant serotype at that time was Den-2, over the last few years it has changed to Den-3 serotype (21-23). $1^{\text {st }}$ dengue pandemic occurred in 1998, in which 1.2 million cases from 56 different countries were reported of DF and DHF. Recently a new subgenotype is originated from indian sub-continent and later spread to other countries, this subgenotype was also a major cause of pandemic (24).

\section{Characteristics of Dengue Virus}

Dengue virus is a single stranded RNA virus belongs to genus flavivirus from family flaviviridae, also known as arbovirus (25). The virus genome is approximately $11 \mathrm{~KB}$ in length. Mature virion has three structural protein (core ' $\mathrm{C}$ ', precursor membrane 'prM' and envelope ' $\mathrm{E}^{\prime}$ ) and seven nonstructural proteins (NS1, NS2, NS2a, NS2b, NS3, NS4a, NS4b and NS5) Fig 1. The envelope protein has important functions, it binds to a specific receptor on host cell and allows the virus to be transported through it, it is also related to haemagglutination of erythrocytes, induction of neutralizing antibodies, and protects immune responses (26). It has also an important role in RNA replication and production of infectious virus particles (27). Dengue virus share their antigenic epitopes with other flavivirusses, the sharing leads to production of cross reactive antibodies and hence, interfere serological analysis. Antibodies directed to the prM protein are species specific and are beneficial for seroepidemological research on dengue (28).

\section{Vector of Dengue Infection}

Dengue is a mosquito born disease, Aedes aegypti, Aedes albopictus and Aedes polynesiensis play a central role in transmission of dengue virus. Aedes Aegypti is the primary and most critical vector and the rest two depend on geographical region (29). In some countries like Singapore, Thailand, India, and Mexico, Aedes albopictus has been found in the transmission of dengue while Aedes Aegypti can transmit virus in both tropical and sub-tropical region. It is a day biting mosquito and rests mostly in cool and dark places or indoors particularly in residing rooms, bed rooms and areas where small collection of water along with flowerpotsare found(30). It is difficult to control it, because it breeds in polluted water, plant saucers, flower vases, uncover water tanks, barrels, water coolers and other places where rain water collect and stored, it lays eggs in water bins around the homes, which take 10 days to be hatched $(31,32)$. Damp condition offers suitable breeding opportunity to mosquito larval that's why the epidemic prevails over proportionally in rainy seasons, however rise in temperature shorten their life span $(30,33)$.

Fig 2 shows the transmission of Dengue virus infection, the infected mosquito take longer to bite as compare to uninfected one. This increased time corresponds dengue virus infection of organs known to control or influence the activities associated with feeding(34). Several research endorse the presence of transovarial dengue virus transmission in infected female Aedes Aegypti, allowing the virus to spread their progeny, such process act as a reservoir for virus to support during interepidemic period(35).

\section{Pathogenesis}

The average incubation period of Dengue virus is $07-10$ days as soon as the infected mosquito bites, showing its symptoms regarding to the victim 's age and immune status, the symptoms (intense fever, constitutional signs) are observed for a week, having entered (virus) host circulation simultaneously grip the body through white blood cells. Dendritic cells, mast cells and endothelial cells are usually infected by the virus through endless series of replication with in B-cell, macrophages and in monocytes(36), probably ( Dengue virus ) effect spleen, bone marrow, leukocytes, lymph node, liver heart, stomach, thymus, kidney plus also disrupt blood brain barrier (37). There is possibility of both early recovery and severity in preliminary stage (38). Occurance of overstimulation of immune system during infection tenure the virus dwindled away whereas the process leads to over production of cytokines, which badly paralyze the monocytes, hepatocytes and endothelial cells, as they have TNF- $\alpha$, IFN- $\alpha$ and various chemical mediators. Both infected and non-infected dendritic cells are activated by IFN- $\alpha$ and TNF- $\alpha(39,40)$. enormous number of various mediators and cytokines ascend vascular permeability, shock, leakage of plasma, hemostatic abnormality and hypovolemia, and it witnesses that endothelial cells go through apoptosis which disrupting endothelial cell barrier and causes generalized vascular leak syndrome(41).

Dengue infection is caused by any of the dengue viral serotype. Generally, infection with one serotype confering to produce lifelong immunity against that particular serotype but not other, however new serotype infection jeopardize life, because antibodies produce during $1^{\text {st }}$ infection were unable to resist, during this condition large number of antibodies were produce which lead to severe infection. This scenario is called antibodies dependent enhancement. Preexisting antibodies cross- reacts with a new stereotype of secondary infection and cause extreme attack. Antibodies Coated virions can take up quickly by macrophages, monocytes and dendritic cells. This condition lead to high viral load, and dendritic cell present large number of antigen presentation to the T-cells which result in huge amount of Tcell activation and proliferation of memory T-cells, this condition lead to low expression of IFN- $\gamma(42)$. Common pathological findings of this infection include peritoneal effusions, petechial hemorrhages, pulmonary edema, and serous pleural. There is no such data available which show the severity of infection belongs to which particular serotype or which serotype has significant outcome.

\section{Clinical Classification}

Dengue infection can turn threatening from asymptomatic state to more challenging stages that may lead to death if not properly managed(11, 43).Fig 3 shows the clinical classification of infection,WHO classifies Dengue infection into two categories complicated infection and uncomplicated infection. Plasma escape phase, DHF,DSS are risked severelyand the remaining conditions are thought to 
be mild and not complicated(11). According to 1997 WHO classification (44)of Dengue infection are classified into;

\section{Un-differentiated Fever (UF)}

2. Dengue Fever $(\mathrm{DF})$

3. Dengue hemorrhagic fever (DHF)

a. DHF without shock

b. DHF with shock

\section{CLINICAL FEATURES, DIAGNOSIS AND MANAGEMENT OF DEN INFECTION}

Undifferentiated Fever (UF)

Mostly this stage is hard to be differentiate and diagnosed from other viral infections, incase it is cured in short period. This stage is common in primary infection, but might also chance to occur in the initial stage of secondary infection.

\section{Dengue Fever (DF)}

WHO reports that the symptoms of DF become worsens and majority of patients characterize high grade fever along with retro-orbital pain, maculopapolar rash, severe headache, myalgia, intense joint pain, low appetite, abdominal pain, diarrhea and vomiting like DSS patients also show these symptoms. In the majority of cases the early signs (melena, gum bleeding, hyper menorrhea, epistaxis and hemoglobinuria) are missed due to the busy schedule of health care professionals, these signs can help in early detection of infection. Tourniquet test is also an important tool in the early investigation of the virus Patients usually recover in about 2-7 days or progress to more severe stages $(45,46)$. Due to severe joints pain and myalgia DF is also named break bone fever(43, 47). Approximately 50$82 \%$ of DF patients have peculiar cutaneous $\operatorname{rash}(10,48)$. Preliminary rash is due to capillary dilation and present as a temporary facial flushing erythema, commonly observed in first 02 days of fever. The second phase of rashes usually appears from the third day of fever remains up to 01 week. In some cases these lesions may merge with one another and give a look of widespread confluent erythmatosus with clear look of blood spots with large number of sparing, giving an appearance of "white island in a sea of $\operatorname{Red}^{\prime}(49)$. These rashes are severe in about $16-27 \%$ of cases, and cause pruritus $(50,51)$. In most of the cases bleeding does not happen usually at this stage, It is an incapacitating disease state however prognosis is favorable $(45,52)$. According to 2011 case definition of dengue fever by WHO, Dengue fever is suspected in a patient with excessive fever and two of the following signs, i.e. rash, myalgia, joint pain, headache, retro-orbital pain, or common bleeding includes hematemesis, petechiae, melena, gum bleeding or having tourniquet test positive. Clinical finding of dengue patients includes leukopenia $\left(\leq 5,000 \mathrm{cell} / \mathrm{mm}^{3}\right)$, thrombocytopenia $\left(\leq 150,000 \mathrm{cell} / \mathrm{mm}^{3}\right)$ and hematocrit level increase up to 5 $10 \%$.

\section{Management of DF}

Febrile phase of both DF and DHF are treated with antipyretic Paracetamol, other non-steroidal antiinflammatory drugs such as diclofenac sodium and aspirin are contra-indicated infection because it causes gastric irritation. Paracetamol dose should not be exceeded more than $60 \mathrm{mg} /$ day, as it can cause liver injury, that along with dengue infection may be result in more complications. If the temperature is not control with paracetamol slightly warm sponging is recommended (53), and patient should be managed with soft and nutritious diet or oral rehydration fluids. In case of vomiting antiemetic Domeperidone should be given to patient. Cimetidine is effective in patients with GIT bleeding or at risk of such bleeding due to low platelet count. In initial febrile phase, management of intravenous fluid is generally not necessary, except patients with intense dehydration. Hematocrit level and platelet count should be regularly checked from the third day of fever, because the chances of plasma escape are high during this time (53). Dengue infection is mostly mild and patient may recover soon at home, but when patient shows any serious sign like bleeding, clinical deteriotion, change in the consciousness or any other finding in lab diagnosis the patient should be immediately hospitalized and so are the abstain from the edieble stuffs due to risk of dehydration. Moreover, patients having high risk of DHF must be monitored regularly.

\section{Dengue Hemorrhagic Fever (DHF)}

DHF is mostly occurring during secondary infection however in some cases it occurs in primary infections, patients who have high viral load and slower viral clearance rate and in infants it may occur during primary infection because of inherited attained dengue antibodies from mother(54, 55). DHF initial symptoms are almost identical to DF, During DHF the high grade fever remain up to one week. In infants it causes splenomegaly and hepatomegaly. During DHF hemorrhagic tendency may occur in any one of the following conditions: ecchymosis, mucosal and gingival bleeding, petechiae, GIT hemorrhage, purpura, hematemesis, tourniquet positive and hepatomegaly(56). Generally the most common hemorrhagic conditions found in DHF patients are blood vessels injury, petechiae. GIT Bleeding is observed in critical conditions while gingival and epistaxis are unusual signs. Hemorrhagic episodes in DHF are related to multi factors, i.e. Platelet disorders, the defect in coagulation pathway and vascular abnormalities, however platelet disorder may lead to thrombocytopenia and damage platelet fragile blood vessels and hence cause hemorrhage(56-60).

According to U.S. Pan organization and WHO guidelines DHF have following manifestations: high temperature, hemorrhagic features, platelet count less than $\leq 100,000 / \mu \mathrm{l}$ (thrombocytopenia), increase capillary permeability and plasma escape from capillaries which lead to increase hematocrit level(61). Clinically DHF has three phases i.e. Febrile, plasma leakage and convalescent phase. During $1^{\text {st }}$ phase patient may face high temperature with constitutional signs and facial erythema(46), and the phase is marked through macular lesions and hemorrhagic tendencies, they persist up to one week and then drop to normal level, in some patients convalescence phase start soon but in some patients infection turn more severe and plasma leakage start(62). Plasma leakage phase characterized by Shock, fluctuation of pulse rate, hepatomegaly, cyanosis, pericardial and pleural effusions and ascites(63). Intense ecchymosis and GIT bleeding, Erythema, Bradycardia, pallor and confluent petechial rashes are the clinical features of this phase. According to WHO 2011 dengue suspected case criteria, DHF cases were defined as:

Foremost criteria: elevated HCT $\geq 20 \%$, plasma escape, detection of ascites, pleural effusion.

Minor criteria: $1>$ tourniquet positive or bleeding

$2>$ thrombocytopenia $\left(\leq 100,000\right.$ cells $\left./ \mathrm{mm}^{3}\right)$ 
In plasma leakage stage it is not nessecary that patient may have hemorrhage or tourniquet positive, patient plt may be around 100,000 cells $/ \mathrm{mm}^{3}$.

DHF severity is divided into four grades.

DHF Grade I: Positive tourniquet test, No shock

DHF Grade II: Spontaneous bleeding, No shock

DHF Grade III: Shock

DHF Grade IV:intense shock, unstable pulse rate.

\section{Management of DHF}

Fluid electrolytes maintenance is extremely important in controlling DHF phase. Platelet count less than 100,000 (unit) and hematocrit level $>20 \%$ is a clear indicator of plasma leakage. According to the severity of the infection DHF is divided into 04 grades i.e. regular monitoring of complications, enough fluid management, regular assessment of fluids and electrolyte balance. Patient should be regularly supervised after 1-2 hours, to detect early signs of shock on time. Packed cell volume should ideally be investigated twice a day. The rate of fluid management depend on plasma leakage, this rate may be increase assessment of clinical signs such as frequent urination, increase PCV (53). Liver enzymes should be regularly monitored, as liver failure and hepatic encephalopathy are the known related complications of DHF. Controversy exists in the use of fluids, WHO recommends crystalloid solution, while some research advise, that initial resuscitation using colloid had vital role in rapid restoring of hematocrit level, pulse rate and cardiac index (64).

Platelet transfusion is necessary in serious cases, possessing low platelet and visible signs of hemorrhagic, although the exact important platelet count for transfusion is unknown that has a significant influence on active hemorrhage, the critical phase lasts for 02 days then rever to convalescent phase $(65,66)$. After the fall of pcv and increase in plt count fluid therapy should be stopped, awareness of leakage phase is must or else overzealous fluid administration create complexity.

\section{Complications of DHF}

DHF may create bundle of complexities like encephalopathy, hemolytic uremic syndrome, defect in coagulation mechanism, liver failure, myocarditis and renal failure (29). In past epidemics these fearing scenarios were peculiar, over the past few years these complications were reported in increased frequency, it is because of increase in the DHF cases (67).

\section{Dengue Shock Syndrome}

DSS is the most fatal stage of Den infection, it claims decimating masses. Severe plasma loss from the circulation lead to DSS. Critical DHF patients may progress to this phase (68). The major clinical manifestations of this phase are; weak pulse rate, circulatory failure, cold and clammy skin and prolong capillary refill. When the body temperature below the normal, at that stage the risk of shock is increase. During this phase the patient may complain intense abdominal pain and regular vomiting shortly earlier than the onset of shock (69). The shock duration is less, if not then manage properly, it can cause death within 24 hours after the onset of shock (70). Patient may recover within 02-05 days from this phase with short supportive treatment duration of 07-10 days. Shock is often along with metabolic acidosis.

\section{Management of DSS}

It is the most critical and medical emergency phase, each and every minute is important, without delay fluid management (fluid swoping), Oxygen administration is also recommended, because of severe plasma escape. Delayed or not enough fluid can damage multi organs that may result in death. Clinical signs (pulse rate, capillary refill time) need to be monitored regularly, through pulse oxymeter oxygen saturation should be monitored. Important tests (blood grouping, cross match, electrolytes, liver function test, CBC) should be performed immediately. Electrolytes imbalance and acid base disturbance can commonly arise in prolong shock there is a high risk of disseminated intravascular coagulopathy, which can lead to intense shock and massive bleeding. Hence coagulation profile should be measured and in case of any complication platelet/ fresh frozen plasma or cryoprecipitate should transfused to patient. Ideal fluid management includes crystalloid (Ringer 's lactate) and colloid (Dextran 70) (71). Colloid found in normalizing pulse rate, $\mathrm{PCV}$ and heart related index more quickly with no major bad effects and as a result may considered preferred solution for acute resuscitation in dengue shock syndrome, as compared to crystalloid fluid (72). Intravenous fluids should be closely supervised for about 1-2 hour period of time during 24 hours. After adequate fluid management, if the shock elongates then the patient should be investigated for myocarditis and internal bleeding, if any abnormality is observed in cardiac enzymes or electrocardiogram patient should be treated with inotrophes in an intensive care setting. In Prolong shock in spite of decrease in hematocrit level after preliminary fluid replacement, resuscitation after transfusion of plasma or plasma expanders, patient may be suspected internal bleeding. Blood transfusion than may be advised(73).

\section{LABORATORY FINDINGS}

In initial phase, most of the cases have normal serum biochemistry along with normal count of platelet but in severe case low WBCs, low platelet count and raised liver enzymes are common lab findings. Common clinical signs observed in DHF are thrombocytopenia, Haemoconcentration, raise liver enzymes and leucopenia. The levels of both liver enzymes are elevated in childrens who have increased risk of DHF than in those individuals with classical dengue fever(74). Leucopenia is a strong indicator of DHF. Decreased level of complement protein, hypoalbuminaemia, and abnormal coagulation profile are frequently found in DHF. Coagulation abnormalities suggest that there is activation of both coagulation and fibrinolysis during acute phase, and in severe condition the degree of this activation become high(75). During prolong shock following clinical signs are often seems: increased blood urea, hyponatremia and metabolic acidosis. Lipid concentration are also significantly lower in DHF patients(76).

\section{LABORATORY DIAGNOSIS}

Virus isolation, serology and molecular techniques are used to detect Dengue virus. However in some cases, the physicians start the treatment before the results of these assays on the basis of clinical history. Dengue virus are 
investigated in serum, plasma and PBMC, after 2-7 days of the infection. The detection rate is better in PBMC of the infected patient as compare to serum sample (53.8\% vs 18.9 $\%)$ respectively. The detection rate is high in PBMC on day 04 of the infection, while in serum sample it is high in day 05 .

\section{Virus Isolation}

The virus can be isolated during febrile phase from leucocytes, plasma or serum. The virus may also be examined in postmortem specimens such as; thymus, lung, cerebrospinal fluid, lymph nodes, pleural or ascetic fluid, spleen and liver(29). Ideal time to collect blood for analysis is during febrile phase is before the $5^{\text {th }}$ day of illness (before formation of neutralizing antibodies), because the formation of immune complexes also influence virus isolation. The serum sample should be kept at $04-08{ }^{\circ} \mathrm{C}$ for 24 hours, but for longer period of time sample should be stored at $270^{\circ} \mathrm{C}(77)$. Mosquito cell lines are used for cultured, as they are more sensitive and easy to keep at room temperature for approximately 14 days. Presently C636 cell line (obtained from A.albopictus) is commonly used(77).

Virus isolation is mostly executed for studies purposes, because need to understand more about it, take two weeks to study the result. Mosquito inoculation technique is used for critical specimens, as this technique is more sensitive than mosquito cell line(77).For mosquito inoculation technique toxorhynchites splenden and A.albopictus mosquitoes are widely used. Immunofluorescence assay or plaque reduction neutralizing test are usually perform for research purposes, it is used to identify the serotype in primary infection. Immunofluorescence assay is not expensive and give result in about 24-48 hours(78).

\section{Serological Diagnosis}

Mostly serological assays are used for diagnosis of Dengue infection, as they are relatively less expensive and easy to perform compare to other assays. Assays used for serological identification of Dengue virus are; ELISA assay, haemagglutination inhibition test, neutralizing test and complement fixation test. Dengue IgG and IgM ELISA is broadly used as it is cheap, more sensitive and easy to perform (79). On the $5^{\text {th }}$ day of infection nearly all of the patients have measureable IgM antibodies and after 30-60 days from the onset of infection these antibodies become undetectable. The specificity and sensitivity of IgM ELISA are high i.e. $100 \%, 83.9-98.4$ respectively(80).Sensitivity has significant influence in detection of secondary infection, because in secondary infection, secondary immune responses produces large numbers of $\mathrm{IgG}$ antibodies are produced due to stimulation of memory B cell, as well as $\operatorname{IgM}$ antibody to the current infection, IgM capture ELISA is used to compete excessive $\operatorname{IgG}$ with less $\operatorname{IgM}(81)$.Antigen capture ELISA isrecently introduce, it is also used to identify the serotype of Dengue $(82,83)$. The potential of Dengue viruses to agglutinate goose erythrocytes is used within haemagglutination inhibition test, antibodies titers more than fourfold suggesting other flavivirus infection while single antibodies titer $>1 / 2560$ indicating secondary dengue infection, if clinical history of patient also correlate with Dengue infection.
Molecular Detection

Molecular techniques are generally more sensitive and rapid detection than other techniques.

Multiple molecular assays are introduced in past few years. Most commonly used assays are

RT-PCR, and RT-real-time PCR.

RT-PCR is useful in detection of dengue virus in early phase, when antibodies in patient serum is undetectable. RTPCR is extra sensitive more specific than other assays, perform in less time, and easy to perform. specific primers are used to in amplification step to target a specific region of the genome. Serum, plasma or cells may be used to detect Dengue virus(53).

Real time RT-PCR is a one step assay, used to quantifies virus titre in approximately 1.5 hours. Singleplex (detecting one serotype in single reaction ) and multiplex (detecting all four serotypes from a single reaction ) real time PCR assays are used (84-86).

The downside of molecular techniques compare to other assays is relatively its excessive prices and to needextra care while performing.

\section{CONCLUSION}

The compendium of our recent study is to know how to guard ourselves against the hidden enemy, dengue virus. Dengue viral infection is getting disasterous and catastrophic form as its history is self evident. The infection decimates masses globally drawing the attention of health experts to harbor the expected posterity against the disease by accurate management and prognosis apart from both the patients and the concerned authorities or else repentance will not end to the issue. Timely appropriate precautionary measures and allocation of funds ought to be raisedin order not to let worsen the cosmos and tranquility.

\section{REFERENCES}

[1] Thaithumyanon P, Thisyakorn U, Deerojnawong J, Innis BL. Dengue infection complicated by severe hemorrhage and vertical transmission in a parturient woman. Clinical Infectious Diseases. 1994;18(2):248-9.

[2] DuPont HL, Steffen R. Textbook of travel medicine and health: BC Decker Hamilton; 2001.

[3] Pancharoen C, Thisyakorn U, Thisyakorn C. Dengue infection. JOURNAL OF INFECTIOUS DISEASES AND ANTIMICROBIAL AGENTS. 2001;18(3):115-21.

[4] Thisyakorn U, Thisyakorn C. Diseases caused by arboviruses--dengue haemorrhagic fever and Japanese B encephalitis. The Medical journal of Australia. 1994;160(1):22.

[5] Wilder-Smith A, Ooi E-E, Vasudevan SG, Gubler DJ. Update on dengue: epidemiology, virus evolution, antiviral drugs, and vaccine development. Current infectious disease reports. 2010;12(3):15764.

[6] Gibbons RV, Vaughn DW. Dengue: an escalating problem. BMJ: British Medical Journal. 2002;324(7353):1563. 
[7] Wilder-smith A, Foo W, Earnest A, Sremulanathan S, Paton NI. Seroepidemiology of dengue in the adult population of Singapore. Trop Med Int Health. 2004; 9: 305-8.

[8] Gubler DJ. The economic burden of dengue. The American journal of tropical medicine and hygiene. 2012;86(5):743-4.

[9] Thomas EA, John M, Kanish B. Mucocutaneous manifestations of dengue fever. Indian journal of dermatology. 2010;55(1):79.

[10] Gubler DJ. Dengue and dengue hemorrhagic fever. Clinical microbiology reviews. 1998;11(3):480-96.

[11] Organization WH, Research SPf, Diseases TiT, Diseases WHODoCoNT, Epidemic WHO, Alert P. Dengue: guidelines for diagnosis, treatment, prevention and control: World Health Organization; 2009.

[12] Guzman MG, Halstead SB, Artsob H, Buchy P, Farrar J, Gubler DJ, et al. Dengue: a continuing global threat. Nature Reviews Microbiology. 2010;8:S7-S16.

[13] Ramakrishnan L, Radhakrishna Pillai M, Nair RR. Dengue vaccine development: strategies and challenges. Viral immunology. 2015;28(2):76-84.

[14] Halstead SB. Dengue in the Americas and Southeast Asia: do they differ? Revista Panamericana de Salud Publica. 2006;20(6):407-15.

[15] Gubler DJ. Dengue, urbanization and globalization: the unholy trinity of the $21 \mathrm{st}$ century. Tropical medicine and health. 2011;39(4SUPPLEMENT):S3S11.

[16] Organization WH. Dengue and dengue haemorrhagic fever. http://www who int/mediacentre/factsheets/fs117/en/. 2009.

[17] Ferreira GL. Global dengue epidemiology trends. Revista do Instituto de Medicina Tropical de São Paulo. 2012;54:5-6.

[18] Murray NEA, Quam MB, Wilder-Smith A. Epidemiology of dengue: past, present and future prospects. Clinical epidemiology. 2013;5:299.

[19] Gubler DJ. The global emergence/resurgence of arboviral diseases as public health problems. Archives of medical research. 2002;33(4):330-42.

[20] Shepard DS, Coudeville L, Halasa YA, Zambrano B, Dayan GH. Economic impact of dengue illness in the Americas. The American journal of tropical medicine and hygiene. 2011;84(2):200-7.

[21] Nimmannitya S. Dengue haemorrhagic fever: current issues and future research. Asian-Oceanian Journal of Paediatrics and Child Health. 2002;1:1-21.

[22] King C-C, Wu Y-C, Chao D-Y, Lin T-H, Chow L, Wang H-T, et al. Major epidemics of dengue in Taiwan in 1981-2000: related to intensive virus activities in Asia. Dengue bulletin. 2000;24:1-10.

[23] Endy TP, Nisalak A, Chunsuttiwat S, Libraty DH, Green S, Rothman AL, et al. Spatial and temporal circulation of dengue virus serotypes: a prospective study of primary school children in Kamphaeng Phet, Thailand. American journal of epidemiology. 2002;156(1):52-9.

[24] Messer WB, Gubler DJ, Harris E, Sivananthan K, De Silva AM. Emergence and global spread of a dengue serotype 3, subtype III virus. Emerging infectious diseases. 2003;9(7):800.
[25] Kouri G. Dengue: an update. Lancet Infect Dis. 2002;2:33-42.

[26] Guzmán MG, Kouri G. Advances in dengue diagnosis. Clinical and diagnostic laboratory immunology. 1996;3(6):621.

[27] Young PR, Hilditch PA, Bletchly C, Halloran W. An antigen capture enzyme-linked immunosorbent assay reveals high levels of the dengue virus protein NS1 in the sera of infected patients. Journal of clinical microbiology. 2000;38(3):1053-7.

[28] Cardosa MJ, Wang SM, Sum MSH, Tio PH. Antibodies against prM protein distinguish between previous infection with dengue and Japanese encephalitis viruses. BMC microbiology. 2002;2(1):9.

[29] SEARO W. Prevention and Control of Dengue and Dengue Haemorrhagic Fever: Comprehensive Guidelines. New Delhi. 1999.

[30] Thavara U, Tawatsin A, Chansang C, Kong-ngamsuk $\mathrm{W}$, Paosriwong S, Boon-Long $\mathrm{J}$, et al. Larval occurrence, oviposition behavior and biting activity of potential mosquito vectors of dengue on Samui Island, Thailand. Journal of Vector Ecology. 2001;26:172-80.

[31] Perich M, Davila G, Turner A, Garcia A, Nelson M. Behavior of resting Aedes aegypti (Culicidae: Diptera) and its relation to ultra-low volume adulticide efficacy in Panama City, Panama. Journal of Medical Entomology. 2000;37(4):541-6.

[32] Vezzani D, Schweigmann N. Suitability of containers from different sources as breeding sites of Aedes aegypti (L.) in a cemetery of Buenos Aires City, Argentina. Memorias do Instituto Oswaldo Cruz. 2002;97(6):789-92.

[33] Watts DM, Burke DS, Harrison BA, Whitmire RE, Nisalak A. Effect of temperature on the vector efficiency of Aedes aegypti for dengue 2 virus. The American journal of tropical medicine and hygiene. 1987;36(1):143-52.

[34] Platt KB, Linthicum KJ, Myint KS, Innis BL, Lerdthusnee K, Vaughn DW. Impact of dengue virus infection on feeding behavior of Aedes aegypti. The American journal of tropical medicine and hygiene. 1997;57(2):119-25.

[35] Joshi V, Mourya D, Sharma R. Persistence of dengue-3 virus through transovarial transmission passage in successive generations of Aedes aegypti mosquitoes. The American journal of tropical medicine and hygiene. 2002;67(2):158-61.

[36] King CA, Marshall JS, Alshurafa H, Anderson R. Release of vasoactive cytokines by antibodyenhanced dengue virus infection of a human mast cell/basophil line. Journal of virology. 2000;74(15):7146-50.

[37] Hayes EB, Gubler DJ. Dengue and dengue hemorrhagic fever. The Pediatric infectious disease journal. 1992;11(4):311-7.

[38] Libraty DH, Young PR, Pickering D, Endy TP, Kalayanarooj S, Green S, et al. High circulating levels of the dengue virus nonstructural protein NS1 early in dengue illness correlate with the development of dengue hemorrhagic fever. The Journal of infectious diseases. 2002;186(8):1165-8. 
[39] Ho L-J, Wang J-J, Shaio M-F, Kao C-L, Chang D-M, Han S-W, et al. Infection of human dendritic cells by dengue virus causes cell maturation and cytokine production. The Journal of Immunology. 2001;166(3):1499-506.

[40] Chakravarti A, Kumaria R. Circulating levels of tumour necrosis factor-[alpha] \& interferon-[gamma] in patients with dengue $\&$ dengue haemorrhagic fever during an outbreak. Indian Journal of Medical Research. 2006;123(1):25.

[41] Lin C-F, Lei H-Y, Shiau A-L, Liu H-S, Yeh T-M, Chen S-H, et al. Endothelial cell apoptosis induced by antibodies against dengue virus nonstructural protein 1 via production of nitric oxide. The Journal of Immunology. 2002;169(2):657-64.

[42] Halstead SB. Pathogenesis of dengue: challenges to molecular biology. Science. 1988:476-81.

[43] Gupta N, Srivastava S, Jain A, Chaturvedi UC. Dengue in India. 2012.

[44] Ranjit S, Kissoon N. Dengue hemorrhagic fever and shock syndromes. Pediatric Critical Care Medicine. 2011;12(1):90-100.

[45] Ahmed FU, Mahmood CB, Sharma JD, Hoque SM, Zaman R, Hasan MS. Dengue and Dengue Haemorrhagic Fever in children during the 2000 outbreak in Chittagong, Bangladesh. 2001.

[46] Narayanan M, Aravind M, Thilothammal N, Prema R, Sargunam CR, Ramamurty N. Dengue fever epidemic in Chennai-a study of clinical profile and outcome. Indian pediatrics. 2002;39(11):1027-33.

[47] Chen LH, Wilson ME. Dengue and chikungunya infections in travelers. Current opinion in infectious diseases. 2010;23(5):438-44.

[48] Itoda I, Masuda G, Suganuma A, Imamura A, Ajisawa A, Yamada K-I, et al. Clinical features of 62 imported cases of dengue fever in Japan. The American journal of tropical medicine and hygiene. 2006;75(3):470-4.

[49] Meltzer MI, Rigau-Perez JG, Clark GG, Reiter P, Gubler DJ. Using disability-adjusted life years to assess the economic impact of dengue in Puerto Rico: 1984-1994. The American journal of tropical medicine and hygiene. 1998;59(2):265-71.

[50] Thomas EA, John M, Bhatia A. Cutaneous manifestations of dengue viral infection in Punjab (north India). International journal of dermatology. 2007;46(7):715-9.

[51] Chadwick D, Arch B, Wilder-Smith A, Paton N. Distinguishing dengue fever from other infections on the basis of simple clinical and laboratory features: application of logistic regression analysis. Journal of Clinical Virology. 2006;35(2):147-53.

[52] Kabra S, Juneja R, Jain Y, Singhal T, Dar L, Kothari $\mathrm{S}$, et al. Myocardial dysfunction in children with dengue haemorrhagic fever. National Medical Journal of India. 1998;11:59-61.

[53] Malavige G, Fernando S, Fernando D, Seneviratne S. Dengue viral infections. Postgraduate medical journal. 2004;80(948):588-601.

[54] Halstead SB, Lan NT, Myint TT, Shwe TN, Nisalak A, Kalyanarooj S, et al. Dengue hemorrhagic fever in infants: research opportunities ignored. Emerging infectious diseases. 2002;8(12):1474.
[55] Wang W-K, Chen H-L, Yang C-F, Hsieh S-C, Juan C-C, Chang S-M, et al. Slower rates of clearance of viral load and virus-containing immune complexes in patients with dengue hemorrhagic fever. Clinical Infectious Diseases. 2006;43(8):1023-30.

[56] Chiu Y-C, Wu K-L, Kuo C-H, Hu T-H, Chou Y-P, Chuah S-K, et al. Endoscopic findings and management of dengue patients with upper gastrointestinal bleeding. The American journal of tropical medicine and hygiene. 2005;73(2):441-4.

[57] La Russa VF, Innis BL. 11 Mechanisms of dengue virus-induced bone marrow suppression. Baillière's clinical haematology. 1995;8(1):249-70.

[58] Rosenfeld S, Young N. Viruses and bone marrow failure. Blood reviews. 1991;5(2):71-7.

[59] Phanichyakarn P, Pongpanich B, Israngkura P, Dhanamitta S, Valyasevi A, KRISARIN C. Studies on Dengue hemorrhagic fever. III. Serum complement (C3) and platelet studies. Journal of the Medical Association of Thailand. 1977;60(7):301-6.

[60] Organization WH. WHO report on global surveillance of epidemic-prone infectious diseases. 2000.

[61] Organization WH. Dengue haemorrhagic fever: diagnosis, treatment, prevention and control. 1997.

[62] Richards AL, Bagus R, Baso SM, Follows GA, Tan $\mathrm{R}$, Graham RR, et al. The first reported outbreak of dengue hemorrhagic fever in Irian Jaya, Indonesia. The American journal of tropical medicine and hygiene. 1997;57(1):49-55.

[63] Srikiatkhachorn A, Krautrachue A, Ratanaprakarn W, Wongtapradit L, Nithipanya N, Kalayanarooj S, et al. Natural history of plasma leakage in dengue hemorrhagic fever: a serial ultrasonographic study. The Pediatric infectious disease journal. 2007;26(4):283-90.

[64] Wills B. Volume replacement in dengue shock syndrome. 2001.

[65] Chuansumrit A, Tangnararatchakit K. Pathophysiology and management of dengue hemorrhagic fever. Transfusion Alternatives in Transfusion Medicine. 2006;8(s1):3-11.

[66] Isarangkura $\mathrm{P}$, Tuchinda $\mathrm{S}$. The behavior of transfused platelets in dengue hemorrhagic fever. The Southeast Asian journal of tropical medicine and public health. 1993;24:222-4.

[67] Pancharoen C, Rungsarannont A, Thisyakorn U. Hepatic dysfunction in dengue patients with various severity. Journal of the Medical Association of Thailand $=$ Chotmaihet thangphaet. 2002;85:S298301.

[68] Kabra S, Jain Y, Pandey R, Singhal T, Tripathi P, Broor S, et al. Dengue haemorrhagic fever in children in the 1996 Delhi epidemic. Transactions of the royal society of tropical medicine and Hygiene. 1999;93(3):294-8.

[69] Agarwal R, Kapoor S, Nagar R, Misra A, Tandon R, Mathur A, et al. A clinical study of the patients with dengue hemorrhagic fever during the epidemic of 1996 at Lucknow, India. 1999.

[70] Guzmán MG, Alvarez M, Rodriguez R, Rosario D, Vázquez S, Valdés $\mathrm{L}$, et al. Fatal dengue hemorrhagic fever in Cuba, 1997. International Journal of Infectious Diseases. 1999;3(3):130-5. 
[71] Soni A, Chugh K, Sachdev A, Gupta D. Management of dengue fever in ICU. Indian journal of pediatrics. 2001;68(11):1051-5.

[72] Dung N, Day N, Tam D, Loan H, Chau H, Minh L, et al. Fluid replacement in dengue shock syndrome: a randomized, double-blind comparison of four intravenous-fluid regimens. Clinical Infectious Diseases. 1999;29(4):787-94.

[73] Shivpuri A. Dengue-An overview. Dent Med Probl. 2011;48(2):153-6.

[74] Kalayanarooj S, Vaughn D, Nimmannitya S, Green S, Suntayakorn S, Kunentrasai N, et al. Early clinical and laboratory indicators of acute dengue illness. Journal of Infectious Diseases. 1997;176(2):313-21.

[75] Huang Y-H, Liu C-C, Wang S-T, Lei H-Y, Liu H-S, Lin Y-S, et al. Activation of coagulation and fibrinolysis during dengue virus infection. Journal of medical virology. 2001;63(3):247-51.

[76] van Gorp EC, Suharti C, Mairuhu AT, Dolmans WM, van Der Ven J, Demacker PN, et al. Changes in the plasma lipid profile as a potential predictor of clinical outcome in dengue hemorrhagic fever. Clinical Infectious Diseases. 2002;34(8):1150-3.

[77] Callahan JD, Wu S-JL, Dion-Schultz A, Mangold BE, Peruski LF, Watts DM, et al. Development and evaluation of serotype-and group-specific fluorogenic reverse transcriptase PCR (TaqMan) assays for dengue virus. Journal of clinical microbiology. 2001;39(11):4119-24.

[78] Henchal EA, McCown J, Seguin M, Gentry M, Brandt W. Rapid identification of dengue virus isolates by using monoclonal antibodies in an indirect immunofluorescence assay. The American journal of tropical medicine and hygiene. 1983;32(1):164-9.
[79] Roche RR, Alvarez M, Guzmán MG, Morier L, Kourí G. Comparison of rapid centrifugation assay with conventional tissue culture method for isolation of dengue 2 virus in C6/36-HT cells. Journal of clinical microbiology. 2000;38(9):3508-10.

[80] Guzman MG, Kouri G, Soler M, Bravo J, Vega ARdl, Vazquez S, et al. Dengue 2 virus enhancement in asthmatic and non asthmatic individual. Memorias do Instituto Oswaldo Cruz. 1992;87(4):559-64.

[81] Branch SL, Levett PN. Evaluation of four methods for detection of immunoglobulin $\mathrm{M}$ antibodies to dengue virus. Clinical and diagnostic laboratory immunology. 1999;6(4):555-7.

[82] Kuno G, Gubler D, De Weil NS. Antigen capture ELISA for the identification of dengue viruses. Journal of virological methods. 1985;12(1-2):93-103.

[83] NAWA M, ICHIKAWA Y, INOUYE S. Serotyping of dengue viruses by an enzyme-linked immunosorbent assay. Japanese Journal of Medical Science and Biology. 1985;38(5-6):217-21.

[84] Johnson BW, Russell BJ, Lanciotti RS. Serotypespecific detection of dengue viruses in a fourplex real-time reverse transcriptase PCR assay. Journal of clinical microbiology. 2005;43(10):4977-83.

[85] Chien L-J, Liao T-L, Shu P-Y, Huang J-H, Gubler DJ, Chang G-JJ. Development of real-time reverse transcriptase PCR assays to detect and serotype dengue viruses. Journal of clinical microbiology. 2006;44(4):1295-304.

[86] Kong YY, Thay CH, Tin TC, Devi S. Rapid detection, serotyping and quantitation of dengue viruses by TaqMan real-time one-step RT-PCR. Journal of virological methods. 2006;138(1):123-30.

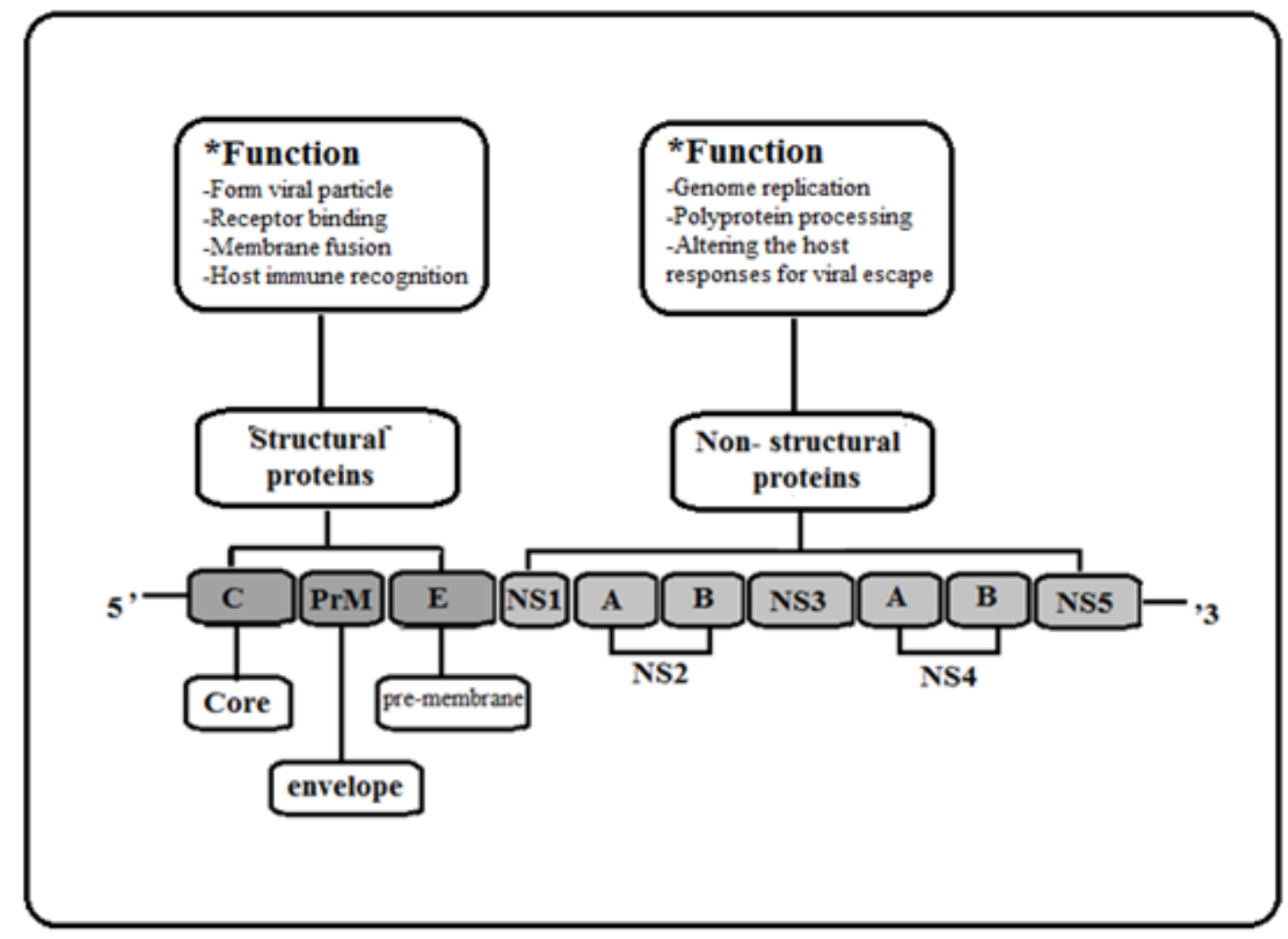

Fig 1. shows Dengue virus genome with structural and non-structural proteins 
Transmission of

Dengue virus

Aedes agypti

A. albopictus

A. polynesiensis

A. scotellaris

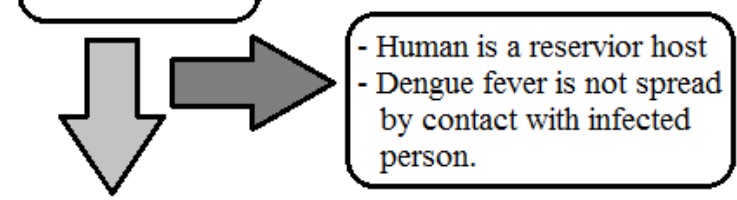

Infected person could

transmit virus if he is

bitten by mosquito

Travel to Dengue

endemic regions

Blood transfusion

Vertical

Transmission

Fig 2. demonstrates the transmission of Dengue viral infection

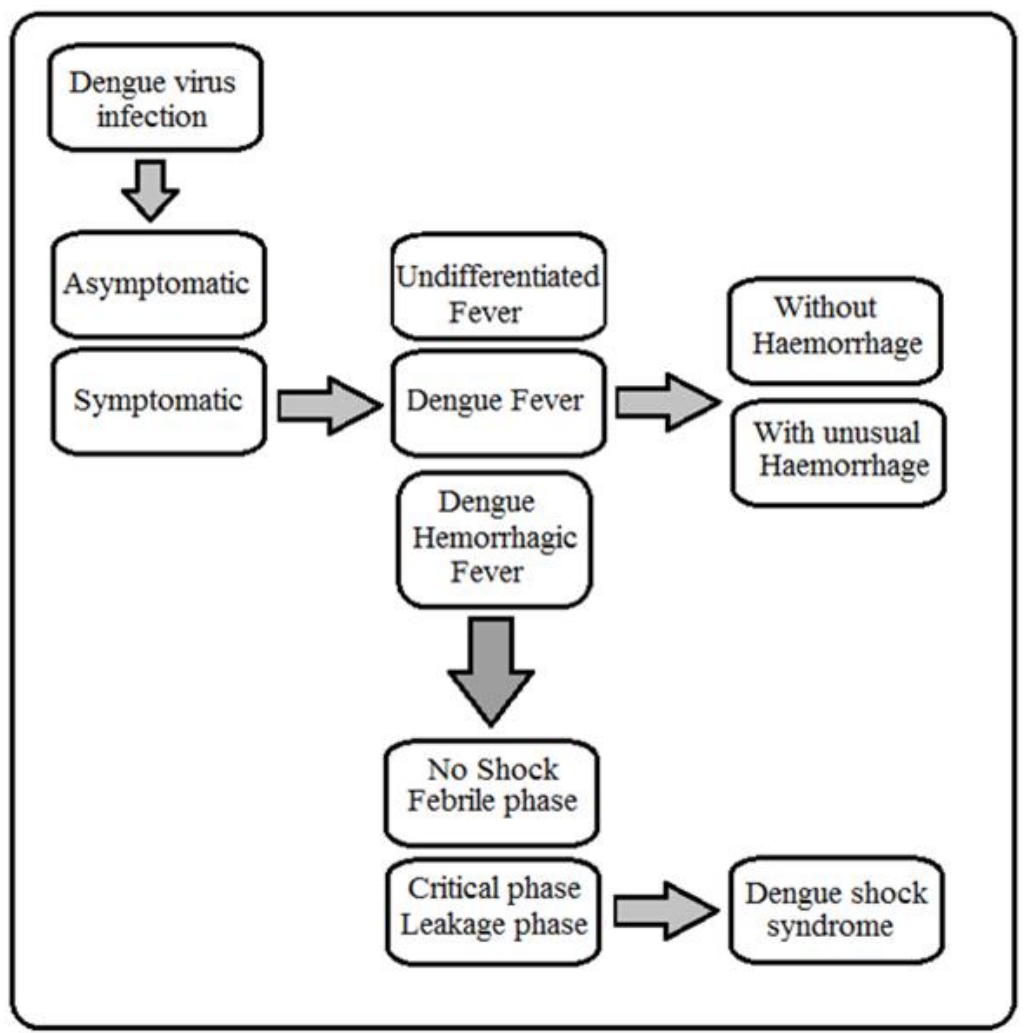

Fig 3. Shows the detail Clicinical classification of Dengue viral infection

Cite article as:Irfan Kalam, Qaisar Ali, Fazal Mabood. Clinical, Diagnosticand Remedial circumference Reflecting Dengue Viral Infection. Res Pharm Healt Sci.2019;5(2):133-141., doi: https://doi.org/10.32463/rphs.2019.v05i02.02 